Jurnal Basicedu Volume 1 Nomor 1 Tahun 2017 Halaman 45-54
Research \& Learning in Elementary Education
http:// stkiptam.ac.id/indeks.php/basicedu

\title{
PENINGKATAN HASIL BELAJAR LUAS BANGUN DATAR MELALUI MODEL KOOPERATIF TIPE JIGSAW BAGI SISWA KELAS V SD NEGERI 003 BANGKINANG KOTA
}

\author{
Rusdial Marta ${ }^{1}$ \\ ${ }^{1}$ Dosen Prodi PGSD Universitas Pahlawan Tuanku Tambusai \\ e-mail : dial.fredo90@gmail.com
}

\begin{abstract}
Abstrak
Penelitian ini dilatarbelakangi dari kenyataan di Sekolah Dasar bahwa pembelajaran sering didominasi oleh guru sebagai sumber informasi dan model pembelajaran yang digunakan pada umumnya bersifat konvensional, sehingga proses pembelajaran kurang menarik bagi siswa dan hasil belajar yang dicapai kurang memuaskan. Berdasarkan data nilai ujian mid semester 2 matematika kelas $V$, masih banyak siswa yang memperoleh nilai di bawah standar.Dari itu peneliti melalui penelitian tindakan kelas ini ingin mencoba meningkatkan hasil belajar Matematika melalui pembelajaran kooperatif tipe Jigsaw pada siswa kelas V SD Negeri 003 Bangkinang Kota. Pelaksanaan pembelajaran melalui pembelajaran kooperatif tipe Jigsaw yaitu dengan langkah-langkah : membagi siswa ke dalam beberapa kelompok yang terdiri dari 4-6 orang tiap kelompok yang disebut dengan kelompok asal. Masing-masing anggota kelompok asal diberikan topik yang berbeda-beda. Setiap anggota kelompok asal yang mendapat topik yang sama bergabung dalam satu kelompok yang disebut dengan kelompok ahli. Dalam kelompok ahli, siswa berdiskusi tentang topik yang akan dibahas sesuai dengan petunjuk Lembar Kerja Siswa (LKS). Selesai berdiskusi, masing-masing anggota kelompok ahli bergabung kembali ke kelompok asalnya untuk menjelaskan topik yang telah dibahas pada kelompok ahli. Setelah itu masing-masing kelompok asal diberikan tes tentang seluruh topik, kelompok yang memperoleh nilai tertinggi diberikan penghargaan. Melalui pembelajaran seperti itu menuntut siswa untuk menguasai seluruh topik yang dipelajari.Dari hasil penelitian yang telah peneliti lakukan, terlihat bahwa hasil belajar siswa meningkat. Nilai rata-rata siswa pada skor dasar 5,06, diadakan tindakan pada siklus I meningkat dengan rata-rata 6,9. Kemudian diadakan lagi tindakan pada siklus II, dengan rata-rata nilai siswa mencapai 8,3. Dari hasil penelitian ini dapat disimpulkan bahwa melalui pembelajaran kooperatif tipe Jigsaw dapat meningkatkan hasil belajar matematika siswa pada kelas V SD Negeri 003 Bangkinang Kota. Oleh sebab itu, disarankan agar guru dapat melaksanakan proses pembelajaran melalui pembelajaran kooperatif tipe Jigsaw dengan tujuan untuk dapat meningkatkan hasil dan minat belajar siswa.
\end{abstract}

Kata Kunci : Hasil belajar, model kooperatif tipe Jigsaw 


\section{PENDAHULUAN}

Matematika dalam kehidupan manusia sangatlah penting, karena matematika dapat melatih seseorang berfikir kritis dan logis, juga bermanfaat dalam melakukan perhitungan dalam kehidupan sehari-hari. Matematika sebagai salah satu disiplin ilmu merupakan pengetahuan yang sangat penting terutama dalam era globalisasi sekarang ini, dengan arti kata dalam perkembangannya, matematika tidak terlepas kaitannya dengan perkembangan ilmu pengetahuan dan teknologi (IPTEK).

Seperti diketahui, era globalisasi sekarang ini menginginkan manusia yang mempunyai pola pikir yang logis dan kritis. Sebagaimana yang diutarakan Sri (2006:1) "bahwa matematika yang merupakan ilmu deduktif, aksiomatik, formal, hirarkis, abstrak, bahasa simbol yang padat arti adalah sebuah sistem matematika. Sistem matematika berisikan model-model yang dapat digunakan untuk mengatasi persoalan-persoalan nyata. Manfaat lainnya adalah dapat membentuk pola pikir orang yang mempelajarinya menjadi pola pikir matematis yang sistematis, logis, kritis dengan penuh kecermatan". Oleh sebab itu matematika sangat perlu dipahami dan dikuasai oleh semua lapisan masyarakat terutama siswa Sekolah Dasar (SD).

Dari uraian di atas, jelas bahwa matematika sangat penting dalam era globalisasi. Matematika harus diajarkan sejak dari SD, dimana pembelajaran matematika di SD harus ditingkatkan kualitasnya, karena SD merupakan kunci pertama dan utama dalam menentukan keberhasilan pembelajaran matematika pada jenjang berikutnya. Pembelajaran matematika di SD mempunyai kedudukan yang sangat penting dalam upaya mencapai tujuan pendidikan matematika yang telah ditetapkan. Tujuan pembelajaran matematika di SD menurut DEPDIKNAS (2006:417) adalah agar siswa memiliki kemampuan.

"1) percaya diri dalam memahami konsep matematika, menjelaskan keterkaitan antara konsep dan mengaplikasikan konsep logaritma, secara luwes, akurat, efisien dan tepat dalam pemecahan masalah, 2) menggunakan penalaran pola dan sifat, melakukan manipulasi matematika dalam membuat generalisasi, menyusun bukti atau menjelaskan gagasan dan pernyataan matematika, 3) memecahkan masalah yang meliputi kemampuan memahami masalah, merancang model matematika, menyelesaikan model dan menafsirkan solusi yang diperoleh, 4) mengomunikasikan gagasan dengan simbol, tabel, diagram atau media lain untuk menjelaskan keadaan atau masalah, 5) memiliki sikap menghargai kegunaan matematika dalam kehidupan, yaitu memiliki rasa ingin tahu, perhatian dan minat dalam mempelajari matematika, serta sikap ulet dan pemecahan masalah".

Tujuan pembelajaran matematika di atas menuntut siswa berfikir kritis dan kreatif. Untuk mewujudkan tujuan pembelajaran matematika, hendaknya guru berusaha melibatkan siswa secara aktif dalam kegiatan pembelajaran. Hal yang dapat dilakukan adalah guru menggunakan berbagai model pembelajaran agar siswa tidak merasa jenuh dalam menerima pembelajaran yang disampaikan.

Berdasarkan observasi peneliti di kelas V SD Negeri 003 Bangkinang Kota pada tanggal 25 Maret 2016, siswa menganggap mata pelajaran matematika adalah mata pelajaran yang paling sulit di antara mata pelajaran lainnya, sehingga siswa kurang semangat dalam belajar matematika. Selain hasil observasi, peneliti juga mengadakan wawancara dengan guru kelas V SD tersebut, yang menyatakan bahwa mata pelajaran matematika memang kurang diminati oleh siswa, karena pada umumnya siswa sangat sulit untuk memahami konsep-konsep matematika sehingga siswa kurang berhasil dalam mencapai tujuan pembelajaran yang diinginkan.

Uraian di atas disebabkan oleh kurang tepatnya seorang guru dalam menciptakan suatu model pembelajaran 
yang sesuai dan menarik bagi siswa, sehingga siswa kurang semangat dan sulit untuk memahami materi pembelajaran. Selain itu, dalam menyampaikan materi pembelajaran guru kurang melibatkan siswa dengan benda-benda konkrit maupun alat peraga dan pendekatan maupun metode pembelajaran yang digunakan kurang tepat dengan materi yang diajarkan. Dalam pembelajaran guru lebih banyak aktif dari siswa, pencapaian indikator yang ditetapkan tanpa memperhatikan tingkat kemampuan siswa terhadap materi yang akan diajarkan.

Dari hal diatas hasil belajar matematika pada umumnya kurang tercapai dengan hasil yang memuaskan. Sebagaimana yang telah peneliti lihat dalam data nilai ujian mid semester 2 Matematika kelas V SD Negeri 003 Bangkinang Kota masih banyak siswa memperoleh nilai di bawah standar, data nilainya tersebut dapat dilihat dalam tabel halaman berikut :

Tabel 1.1 Skor Dasar

\begin{tabular}{|l|l|c|}
\hline No & Nama Siswa & Nilai \\
\hline 1 & BP & 5,25 \\
\hline 2 & JS & 6,00 \\
\hline 3 & MG & 4,07 \\
\hline 4 & MYS & 3,43 \\
\hline 5 & RP & 4,21 \\
\hline 6 & RJP & 2,56 \\
\hline 7 & R & 5,30 \\
\hline 8 & ANC & 3,46 \\
\hline 9 & AM & 3,43 \\
\hline 10 & AH & 5,54 \\
\hline 11 & FM & 5,45 \\
\hline 12 & GOR & 7,20 \\
\hline 13 & LO & 6,51 \\
\hline 14 & OAP & 4,81 \\
\hline 15 & SR & 5,25 \\
\hline 16 & Sa & 4,38 \\
\hline 17 & TJ & - \\
\hline 18 & VMG & 5,53 \\
\hline 19 & YB & 5,57 \\
\hline 20 & FS & 5,57 \\
\hline
\end{tabular}

\begin{tabular}{|l|l|c|}
\hline 21 & RJ & 4,63 \\
\hline 22 & TDP & 6,76 \\
\hline 23 & JM & 5,23 \\
\hline 24 & NEP & 4,82 \\
\hline 25 & AM & 5,65 \\
\hline 26 & Mn & 2,75 \\
\hline Jumlah & 121,16 \\
\hline Rata-rata & 4,66 \\
\hline
\end{tabular}

Salah satu materi dalam pembelajaran matematika di SD adalah tentang geometri. Apabila ditelaah dalam Kurikulum Tingkat Satuan Pendidikan (KTSP), materi geometri ini pada umumnya dipelajari pada setiap kelas, ini membuktikan bahwa geometri merupakan salah satu materi pembelajaran yang perlu mendapat perhatian, dengan tujuan agar geometri tersebut dapat lebih dipahami dan dikuasai oleh siswa sebagaimana mestinya.

Fenomena yang peneliti dapatkan dari hasil wawancara dengan guru kelas V SD Negeri 003 Bangkinang Kota, dalam pembelajaran menghitung luas bangun datar guru hanya menjelaskan konsep-konsep dari materi yang akan diajarkan, kemudian memberikan latihan kepada siswa tentang materi yang telah dijelaskan tanpa menganalisis apakah siswa tersebut sudah paham atau belum. Guru kurang melibatkan siswa dengan alat peraga yang tepat dan cara mengajar yang digunakan masih bersifat konvensional, yaitu cendrung menggunakan metode ceramah. Sehingga pembelajaran lebih didominasi oleh guru yang menyebabkan siswa kurang aktif dalam proses pembelajaran.

Kurikulum Tingkat Satuan Pendidikan (KTSP) menuntut siswa agar lebih aktif dalam proses pembelajaran, dengan tujuan supaya siswa lebih paham dengan apa yang dipelajarinya. Badan Standar Nasional Pendidikan (BSNP) (2006:3) menjelaskan bahwa

"Panduan pengembangan kurikulum disusun antara lain agar dapat memberikan kesempatan kepada siswa untuk : 1) belajar untuk beriman dan bertaqwa kepada Tuhan Yang Maha Esa, 2) belajar untuk memahami dan menghayati, 3) belajar untuk mampu 
melakssanakan dan berbuat secara efektif, 4) belajar untuk hidup bersama dan berguna untuk orang lain serta 5) belajar untuk membangun dan menemukan jati diri melalui proses belajar yang aktif, kreatif, efektif dan menyenangkan".

Berdasarkan kenyataan-kenyataan yang didapatkan, peneliti mencoba untuk mengadakan penelitian tindakan kelas untuk meningkatkan hasil belajar menghitung luas bangun datar pada siswa kelas V SD Negeri 003 Bangkinang Kota dengan menerapkan pembelajaran yang aktif, kreatif, efektif dan menyenangkan yaitu dengan jalan mengkonkritkan materi yang abstrak. Dengan hal seperti itu dapat mengembangkan kemampuan siswa untuk meningkatkan hasil belajarnya.

\section{METODE}

Salah satu model pembelajaran yang dapat menciptakan pembelajaran yang aktif dan menyenangkan adalah melalui pembelajaran kooperatif (cooperative learning). Mohammad (2005:2) menyatakan bahwa "dalam pembelajaran koperatif siswa belajar secara berkelompok, saling membantu satu sama lain. Siswa mengeluarkan ide-ide, konsep-konsep dan keterampilan yang mereka miliki". Dengan hal seperti ini dapat meningkatkan pemahaman siswa terhadap materi pembelajaran, karena siswa saling bekerja sama untuk menuntaskan materi belajarnya. Sehingga dapat meningkatkan hasil belajar siswa.

Dalam Nur (2006:12) dijelaskan bahwa : "pembelajaran kooperatif mempunyai beberapa tujuan yang salah satunya adalah pencapaian hasil belajar. Pembelajaran kooperatif juga bertujuan untuk meningkatkan kinerja siswa dalam tugas-tugas akademik dan perubahan norma yang berhubungan dengan hasil belajar. Pembelajaran kooperatif dapat memberi keuntungan pada siswa yang bekerja sama menyelesaikan tugas-tugas akademik, baik kelompok atas maupun kelompok bawah. Siswa kelompok atas akan menjadi tutor bagi siswa kelompok bawah. Dalam proses tutorial ini, siswa kelompok atas aka meningkat kemampuan akademiknya karena memberi pelayanan kepada teman sebaya yang membutuhkan pemikiran lebih mendalam tentang hubungan ide-ide yang terdapat di dalam materi tertentu".

Senada dengan pendapat Nur di atas, Slavin (dalam Etin 2007:4) mengatakan bahwa :"Pembelajaran kooperatif adalah suatu model pembelajaran dimana peserta didik belajar dan bekerja dalam kelompokkelompok kecil secara kolaboratif yang anggotanya terdiri dari 4 sampai 6 orang, dengan struktur kelompok yang bersifat heterogen. Dimana keberhasilan belajar dari kelompok tergantung pada kemampuan dan aktifitas anggota kelompok, baik secara individual maupun secara kelompok".

Dari kutipan-kutipan di atas jelas bahwa pembelajaran kooperatif (cooperative learning) dapat meningkatkan hasil belajar siswa, karena dalam proses pembelajaran siswa saling ketergantungan antara yang satu dengan yang lainnya dan bertanggung jawab atas materi yang dipelajarinya.

Pada pembelajaran kooperatif, guru tidak lagi berperan sebagai nara sumber satusatunya, tetapi berperan sebagai fasilitator dan motivator dalam proses pembelajaran. Proses pembelajaraan berlangsung dalam suasana keterbukaan dan demokratis, sehingga dapat memberikan kesempatan bagi siswa untuk memperoleh informasi yang lebih banyak tentang materi yang dipelajari dan dapat meningkatkan keterampilan sosial sebagai bekal dalam hidup bermasyarakat.

Penerapan pembelajaran kooperatif salah satunya yaitu dengan tipe Jigsaw. Dalam tipe Jigsaw ini menuntut adanya keterlibatan semua anggota kelompok. Sebagaimana yang diungkapkan oleh Mohammad (2005:63) bahwa:

"Dalam Jigsaw peserta didik bekerja dalam tim-tim heterogen, peserta didik ditugasi mempelajari bab atau bahan-bahan lain untuk dibaca dan diberikan lembar ahli yang berisi topik yang berbeda untuk setiap anggota tim agar saat membaca topik dapat 
memfokuskan pada topik tersebut. Apabila telah selesai membaca, peserta didik dari tim yang berbeda dengan topik yang sama bertemu dalam sebuah "kelompok ahli" untuk membahas topik mereka. Setelah dibahas dalam kelompok ahli, peserta didik kembali pada tim asal mereka dan secara bergantian mengajar teman satu timnya tentang topiktopik keahlian mereka. Akhirnya peserta didik diberi kuis tentang seluruh topik".

Dari penjelasan tentang Jigsaw di atas, tipe Jigsaw memiliki keunggulan, yaitu dapat meningkatkan tanggung jawab siswa terhadap pembelajarannya sendiri dan juga pembelajaran orang lain. Siswa tidak hanya mempelajari materi yang diberikan tetapi juga harus siap memberikan dan mengajarkan materi tersebut kepada anggota kelompoknya. Dengan demikian siswa saling ketergantungan antara yang satu dengan yang lainnya.

Berdasarkan keunggulan dari pembelajaran kooperatif tipe Jigsaw di atas dan kendala yang ditemui di kelas V SD Negeri 003 Bangkinang Kota dalam pembelajaran matematika, maka pembelajaran kooperatif tipe Jigsaw ini cocok diterapkan, karena pembelajaran kooperatif tipe Jigsaw ini melatih siswa untuk bertanggugjawab terhadap materi yang dipelajari dan saling bekerja sama antara yang satu dengan yang lain. Sehingga siswa akan lebih serius dalam belajar. Melihat keunggulan dari pembelajaran kooperatif tipe Jigsaw, maka peneliti menggunakan pembelajaran kooperatif (cooperative learning) tipe Jigsaw dalam penelitian tindakan kelas dengan judul Peningkatan Hasil Belajar Luas Bangun Datar Melalui Model Kooperatif Tipe Jigsaw Bagi Siswa Kelas V SD Negeri 003 Bangkinang Kota.

Penelitian Tindakan Kelas ini dilaksanakan di SD Negeri 003 Bangkinang Kota. Penelitian ini dilakukan pada semester dua bulan Januari s/d Juni tahun ajaran 2015/2016 pada kelas V SD Negeri 003 Bangkinang Kota dengan jumlah peserta didik 26 orang yang terdiri dari 15 perempuan dan 11 laki-laki. Terhitung dari waktu perencanaan sampai penulisan laporan hasil penelitian. Pelaksanaan penelitian tindakan ini dimulai dari tanggal 26 Mei 2015 dan berakhir pada tanggal 10 Juni 2015. Penelitian ini dilakukan sebanyak 2 siklus dengan rentang waktu 3 kali pertemuan (9 jam pelajaran). Siklus I dilakukan dalam 2 kali pertemuan dengan alokasi waktu 3 jam pelajaran 1 kali pertemuan dan siklus II dilakukan 1 kali pertemuan dengan alokasi waktu 3jam pelajaran.

\section{HASIL PENELITIAN DAN PEMBAHASAN SIKLUS I}

Pelaksanaan pembelajaran yang aktif dan menyenangkan sangat dibutuhkan oleh siswa Sekolah Dasar, pembelajaran yang menyenangkan itu dapat dilihat pada saat siswa bekerja sama dalam kelompok. Di dalam kelompok siswa saling tolong menolong, siswa dapat dengan mudah memahami materi pelajaran. Hal ini sesuai dengan yang terdapat dalam Nur (2006:12) menyatakan bahwa "Bembelajaran kooperatif mendasarkan suatu ide bahwa siswa bekerja sama dalam kelompok dan sekaligus bertanggungjawab pada aktivitas belajar anggota kelompoknya, sehingga seluruh anggota kelompok dapat menguasai materi pelajaran dengan baik".

Dalam Mohammad

(2004:69)

menyatakan bahwa langkah-langkah pembelajaran kooperatif tipe Jigsaw ada lima yaitu "Membaca topik ahli, diskusi kelompok ahli, laporan tim, kuis dan penghargaan tim". Berdasarkan pendapat tersebut peneliti telah melaksanakan langkah-langkah pembelajaran kooperatif tipe Jigsaw pada pelajaran matematika dengan materi menghitung luas bangun datar sesuai dengan rencana pembelajaran kooperatif tipe Jigsaw yang dirancang sendiri oleh peneliti, dengan langkah-langkah sebagai berikut :

a. Membaca topik ahli

Hal pertama yang peneliti lakukan adalah membentuk siswa atas 6 kelompok. satu kelompok terdiri dari 4 orang siswa yang 
disebut dengan kelompok asal, pembagian kelompok siswa di dasarkan atas nilai yang diperoleh pada skor dasar dan jenis kelamin. Setelah kelompok terbentuk siswa diminta duduk dalam kelompoknya. Guru membagikan topik yang berbeda pada masing-masing anggota kelompok asal (kelompok asal 1, 2, 3 dan 4) yaitu tentang menemukan kembali rumus luas belah ketupat, jajar genjang, trapesium dan layang-layang dan dapat menghitung luas bangun datar tersebut sesuai dengan rumus untuk didiskusikan pada kelompok ahli dan menugasi siswa membacanya.

b. Diskusi kelompok ahli.

Masing-masing anggota kelompok asal yang mempunyai topik yang sama bergabung dalam satu kelompok yang disebut kelompok ahli (kelompok ahli belah ketupat, layang-layang, jajar genjang dan trapesium). Pada kelompok ahli, guru membagikan LKS sebagai petunjuk untuk diskusi, selanjutnya guru membimbing siswa dalam diskusi. Selesai diskusi guru menugasi siswa melaporkan hasil diskusi kelompok ahlinya tentang topik ahli yang telah dibahas ke depan kelas.

c. Diskusi kelompok asal

Selesai diskusi pada kelompk ahli siswa diminta bergabung kembali pada kelompok asal. pada kelompok asal siswa dituntut untuk berdiskusi menyampaikan topik yang dipelajari dalam kelompok ahli kepada anggota kelompok asalnya.

d. Tes

Langkah berikutnya adalah pemberian tes kepada masing-masing kelompok asal. Pemberian tes dilakukan diakhir pelajaran. guru memberikan 4 butir soal dan siswa menjawab pada kertas selembar yang telah disediakan oleh peneliti.

e. Penghargaan

Setelah memberikan tes, guru memberikan penghargaan bagi kelompok asal yang memperoleh nilai tertinggi. Dalam penelitian ini peneliti memberikan tingkat penghargaan kepada kelompok asal III dengan nilai kelompok 8. Setelah pembelajaran siklus satu terlaksana hasil belajar siswa meningkat. hal ini dapat dilihat pada grafik 1 berikut:

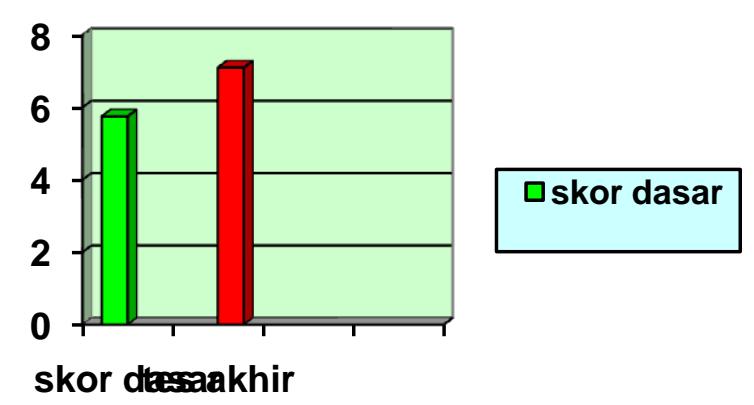

Grafik 4.1

Dari analisis penelitian siklus I nilai rata-rata skor dasar 5,8 dan dapat dilihat pada diagram batang berwarna hijau. Setelah dilakukan tindakan nilai rata-rata siswa meningkat yaitu 6,9 yang digambarkan dengan diagram batang warna merah. Berdasarkan hasil pengamatan siklus I yang diperoleh maka direncanakan untuk melakukan siklus II karena ada 10 orang anak yang memperoleh nilai di bawah rata-rata. untuk itu penelti melanjutkan penelitian pada siklus II.

\section{SIKLUS II}

Guru harus dapat memperhatikan perbedaan yang ada pada siswa karena tiap individu mempunyai karakteristik yang berbeda. Menurut Rochman Natawijaya (dalam Rosna, 2006:43) "Belajar adalah proses pembinaan yang terus menerus terjadi dalam diri individu yang tidak ditentukan oleh unsur ketururunan, tetapi lebih banyak ditentukan oleh faktor-faktor dari luar anak". Dalam belajar siswa banyak memperoleh dari guru, maka guru harus lebih memahami kembali ketiga aspek dalam pendidikan yaitu yang belajar, proses belajar dan situasi belajar. Adpun yang menjasi subjek belajar adalah anak didik atau siswa yang secara individu atau kelompok mengikuti proses pembelajaran dalam suasana tertentu.

Guru sebagai penggerak dan pengatur proses pembelajaran sudah seharusnya dapat 
mengaktifkan semua peserta didik tanpa terkecuali agar potensi yang ada pada siswa dapat tergali dan berkembang. Guru harus dapat memberikan motivasi kepada siswa dalam pembelajaran. Peran guru dalam membelajarkan siswa sangat besar, upaya menimbulkan motivasi anak untuk belajar sangatlah berat seperti yang dinyatakan oleh Rochman (dalam Rosna, 2006:70)

Peran guru dalam memberikan motivasi anak adalah mengenal setiap siswa yang diajarkannya secara pribadi, memperlihatkan interaksi yang menyenangkan, menguasai metode dan tekhnik mengajar serta menggunakannya dengan tepat, menjaga suasana kelas supaya siswa terhindar dari konflik dan yang amat penting memperlakukan siswa sesuai dengan keadaan dan kemampuannya.

Pembelajaran menyelesaikan masalah yang berkaitan dengan luas bangun datar pada siklus II ini, peneliti melakukannya sama seperti siklus I sesuai dengan perencanaan dan langkah-langkah pembelajaran kooperatif tipe Jigsaw sebagai bertikut :

a. Membaca topik ahli

Pada siklus II guru tidak lagi memberikan tes awal kepada siswa, karena skor akhir dari siklus I peneliti jadikan skor awal pada siklus II. Dan guru tidak membentuk kelompok siswa yang baru, guru hanya menugasi siswa duduk pada kelompok asal dan guru memberikan topik yang berbeda pada anggota masing-masing kelompok asal (kelompok asal 1, 2, 3 dan 4) yaitu menyelesaikan masalah yang berkaitan dengan luas bangun datar (soal cerita tentang luas belah ketupat, layanglayang, jajar genjang dan trapesium), selanjutnya guru menugasi siswa membaca topik yang telah diberikan

b. Diskusi kelompok ahli.

Masing-masing anggota kelompok asal yang mempunyai topik yang sama bergabung dalam satu kelompok yang disebut kelompok ahli (kelompok ahli belah ketupat, layang-layang, jajar genjang dan trapesium). Pada kelompok ahli, guru membagikan LKS sebagai petunjuk untuk diskusi, selanjutnya guru membimbing siswa dalam diskusi. Pada siklus II guru lebih membimbing siswa secara merata dan lebih memperhatikan kebutuhan siswa, sehingga siswa lebih semangat pada saat diskusi. Selesai diskusi guru menugasi siswa melaporkan hasil diskusinya ke depan kelas.

c. Diskusi kelompok asal

Selesai diskusi pada kelompk ahli siswa diminta bergabung kembali pada kelompok asal. pada kelompok asal siswa dituntut untuk berdiskusi menyampaikan topik yang dipelajari dari kelompok ahli kepada anggota kelompok asalnya.

d. Tes

Langkah berikutnya adalah pemberian tes kepada kepada semua kelompok asal. Pemberian tes dilakukan diakhir pelajaran. guru memberikan 4 butir soal dan siswa menjawab pada kertas selembar yang telah disediakan peneliti.

e. Penghargaan

Bagi kelompok asal yang memperoleh nilai tertinggi, guru memberikan tingkat penghargaan. Dalam penelitian ini peneliti memberikan penghargaan kepada kelompok asal 1 dengan nilai kelompok 9.

Pembelajaran penyelesaian masalah yang berkaitan dengan luas bangun datar pada siklus II ini Sudah berjalan dengan baik, dan dilaksanakan sesuai dengan perencanaan. pada siklus II peneliti melakukan pembelajaran dengan 1 kali pertemuan dengan alokasi waktu 4jam pelajaran (4 x 35 menit). Berdasarkan hasil pengamatan dari hasil belajar siswa, siswa dapat menyelesaikan soal tes yang diberikan dengan baik. Cara guru dalam membimbing siswa berdiskusi sudah cukup merata dan pembagian alokasi waktu yang telah dilaksanakan sudah berjalan dengan baik.

Dari hasil analisis penelitian siklus II nilai rata-rata kelas mencapai 8,3 berikut peneliti 
sajikan grafik peningkatan nilai rata-rata kelas dari siklus I ke siklus II

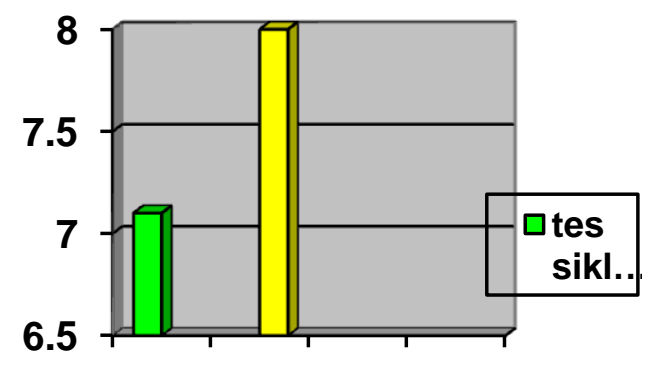

tes sthksısiklus II

\section{Grafik 4.2}

Pada siklus I nilai rata-rata kelas 6,9 yang digambarkan dengan diagram batang warna hijau. Setelah dilakukan tindakan pada siklus II nilai rata-rata siswa meningkat menjadi 8,3 yang digambarkan dengan diagram batang warna kuning. Berdasarkan hasil pengamatan siklus II yang diperoleh maka pelaksanaan siklus II sudah baik dan guru sudah berhasil dalam usaha peningkatan hasil belajar siswa dalam pembelajaran penyelesaian masalah yang berkaitan dengan luas bangun datar dengan menggunakan pendekatan kooperatif tipe jigsaw bagi siswa kelas V SD N 003 Bangkinang Kota .

Berikut peneliti sajikan peningkatan nilai rata-rata siswa sebelum melakukan tindakan dan setelah melakukan tindakan.

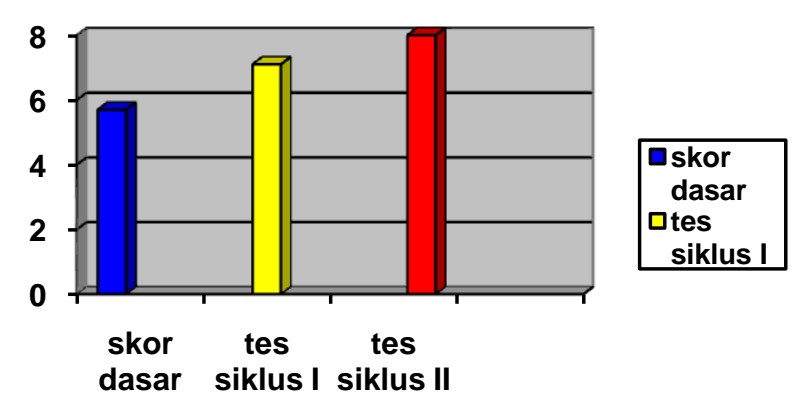

Grafik 4.3

Pada saat peneliti melakukan penelitian, peneliti mengambil skor dasar dari nilai ratarata ujian mid semester II kelas $\mathrm{V}$, dimana nilai rata-rata kelas hanya 5,8 yang dapat dilihat pada diagram batang warna biru.
Kemudian peneliti melakukan tindakan siklus I dalam pembelajaran dengan menggunakan Model Pembelajaran Kooperatif tipe jigsaw nila rata-rata siswa meningkat hingga 6,9 yang digambarkan dengan diagram batang warna kuning. Setelah dilanjutkan dengan siklus II nilai rata-rata siswa meningkat menjadi 8,3 yang digambarkan dengan diagram batang warna merah. BSNP (2006:12) "kriteria ketuntasan untuk masing-masing indikator dalah $75 \%$. Namun disamping itu setiap satuan pendidikan harus manentukan kriteria ketuntasan minimal dengan mempertimbangkan tingkat kemampuan ratarata siswa, kompleksitas kompetensi serta kemampuan sumber daya pendukung dalam penyelenggaraan pembelajaran". Dari hal itu peneliti mengambil ketuntasan yang diterapkan di SD N 003 Bangkinang Kota, yaitu pada mata pelajaran matematika standar ketuntasan minimalnya adalah $70 \%$ Berdasarkan hal itu penelitian ini berakhir di siklus II karena standar ketuntasan klasikalnya sudah melebihi dari target yang ditetapkan.

Pembelajaran yang disajikan pada siklus II, guru dalam memberikan motivasi sangat bagus. Pada proses pembelajaran guru banyak memberikan kesempatan kepada siswa untuk berdiskusi bersama dan bertanya tentang permasalahan yang tidak dimengerti oleh siswa. Untuk itu guru harus mampu menciptakan situasi yang menyenangkan untuk belajar. Sehingga hasil belajar siswa meningkat.

Untuk mencapai hal tersebut sudah seharusnya guru mampu menciptakan pembelajaran yang sesuai dengan kebutuhan siswa. Selain itu, guru juga harus memperhatikan keberhasilan siswa dalam memahami sesuatu dengan cara sesuai dengan tingkat kemampuan siswa. Guru bertugas membelajarkan siswa. Untuk membelajarkan siswa tersebut guru haruslah menggunakan berbagai macam cara agar pembelajaran dapat bermakna bagi siswa, seperti menggunakan pendekatan pembelajaran yang bervariasi, media pembelajaran yang sesuai dengan 
tujuan dan menciptakan suasana belajar yang menyenangkan bagi siswa.

\section{KESIMPULAN}

Dari paparan data dan hasil penelitian serta pembahasan pada halaman terdahulu, maka peneliti dapat menarik beberapa kesimpulan, yaitu:

1. Perencanaan Pembelajaran menghitung luas bangun datar melalui Pembelajaran Kooperatif tipe Jigsaw disesuaikan dengan langkah-langkah melalui pembelajaran kooperatif tipe Jigsaw yaitu: membagi kelompok (kelompok asal dan kelompok ahli), membaca topik ahli, diskusi kelompok ahli, laporan kelompok ahli, tes/kuis, dan penghargaan.

2. Pelaksanaan pembelajaran melalui pembelajaran kooperatif tipe Jigsaw dilaksanakan sesuai dengan perencanaan yang telah disusun, dimana langkah-langkah pembelajarannya dilaksanakan dalam tiga kegiatan pembelajaran yaitu kegiatan awal, kegiatan inti dan kegiatan akhir. Pada kegiatan awal, secara umum langkah-langkah yang dilakukan adalah pengkondisian kelas, membuka skemata siswa yang berhubungan dengan materi yang akan dipelajari, menyampaikan tujuan pembelajaran dan pembentukan kelompok (kelompok asal dan kelompok ahli). Dalam kegiatan inti langkah-langkah yang dilakukan adalah membagikan topik, diskusi kelompok ahli, melaporkan hasil diskusi kelompok, memberikan tes pada kelompok asal dan memberikan penghargaan. Sedangkan pada kegiatan akhir secara umum langkah-langkah yang dilakukan adalah menyimpulkan pembelajaran, memberikan evaluasi secara individu dan menutup pembelajaran.
3. Pembelajaran kooperatif tipe Jigsaw dapat membuat siswa lebih aktif dalam belajar, dapat meningkatkan sikap kerja sama karena pembelajarannya dilakukan secara berkelompok. Hal ini dapat terlaksana karena masing-masing anggota kelompok harus menguasai topik yang telah dibahas dan menyampaikan topik itu kepada anggota kelompoknya. Dengan kata lain pembelajaran kooperatif tipe Jigsaw dapat menumbuhkan tanggung jawab siswa terhadap materi yang dipelajarinya dan harus mengajarkan materi tersebut kepada temannya, sehingga siwa termotivasi untuk aktif dan serius dalam pembelajaran.

4. Meningkatnya hasil belajar siswa dapat dilihat dari rata-rata nilai siswa dari tes awal 5,8 meningkat pada siklus I menjadi 6,9 pembelajaran belum dianggap tuntas jika hasil yang diperoleh di bawah $70 \%$ dan untuk itu penelitian ini dilanjutkan pada siklus II. Ternyata Pelaksanaan tindakan pada siklus II mengalami peningkatan yakni 8,3 yang sudah melebihi dari standar ketuntasan minimalnya. Hal ini merupakan bukti dari pelaksanaan penelitian yang telah dilakukan di SD Negeri 003 Bangkinang Kota telah berhasil.

\section{DAFTAR RUJUKAN}

Antonius Cahya Prihandoko. 2006. Pemahaman dan Penyajian Konsep Matematika Secara Benar dan Menarik. Jakarta : Depdiknas

Aristo Rahadi. 2003. Media Pembelajaran. Jakarta : Depdiknas

Badan Standar Nasional Pendidikan (BSNP). 2006. BSNP. Jakarta : BSNP . 2008. Kurikulum Tingkat Satuan Pendidikan (KTSP). Jakarta : BSNP 
Depdiknas. 2005. Materi Pelatihan Terintegrasi Matematika. Jakarta : Depdiknas

Erman Suherman, dkk. 2003. Strategi Pembelajaran Matematika Kontemporer. Bandung : JICA

Etin Solihatin. 2007. Cooperative Learning Analisis Model Pembelajaran IPS. Jakarta : Bumi Aksara

Harun Rasyid, dkk. 2007. Penilaian Hasil Belajar. Bandung : CV Wacana Prima

I.G.A.K Wardani, dkk. 2002. Penelitian Tindakan Kelas. Jakarta : Universitas Terbuka

Indriyastuti. 2008. Matematika Kelas III SD. Jawa Timur ; PT. Tiga Serangkai Pustaka Mandiri

Karso,dkk.1998.Materi pokok pendidikan matematika I.Jakarta: universitas Terbuka

Kunandar. 2008. Guru Profesional Implementasi KTSP dan Sukses dalam Sertifikasi Guru. Jakarta : PT. Raja Grafindo Persada

Masnur Muslich. 2007. KTSP Dasar Pemahaman dan Pengembangan. Jakarta: Bumi Aksara

Mohammad Nur. 2005. Pembelajaran Kooperatif. Surabaya : Depdiknas

Mulyana. 2007 . Tip dan Trik Berhitung Super Cepat dengan Konsep Rahasia Matematika. Surabaya : Agung Media Mulya

Nur Asma. 2006. Model Pembelajaran Kooperatif. Jakarta : Depdiknas
Sri Subarinah. 2006. Inovasi Pembelajaran Matematika Sekolah Dasar. Jakarta : Depdiknas

Suharsimi Arikunto, dkk. 2004. Evaluasi Program Pendidikan. Jakarta : PT.Bumi Aksara

Ritawati Mahyuddin, dkk. 2008. Hand Out Metodologi Penelitian Tindakan Kelas. Padang: UNP

Rochman Natawijaya. 1992. Psikologi Pendidikan. Jakarta : Depdikbud

Rosna. 2006. Peningkatan Hasil Belajar Geometri Dalam Penbelajaran melalui Penggunaan Media Bangun Datar bagi Siswa Kelas IV SDN 18 Kota Panjang. Skripsi tidak diterbitkan. Padang.PGSD.UNP.

Wina Sanjaya. 2008. Strategi Pembelajaran. Jakarta : Kencana Prenada Media Group

Zahara Djafar. 2001. Konstribusi Strategi Pembelajaran Terhadap Hasil Belajar. Padang : FIP UNP 